\title{
STUDI KASUS TENTANG RASA PERCAYA DIRI, FAKTOR \\ PENYEBABNYA DAN UPAYA MEMPERBAIKI DENGAN \\ MENGGUNAKAN KONSELING INDIVIDUAL
}

\author{
Diana Ariswanti Triningtyas *
}

\begin{abstract}
Abstrak
Pada hakekatnya manusia mempunyai rasa percaya diri, namun antara satu dengan yang lain ada perbedaan yaitu ada yang memiliki rasa percaya diri rendah dan ada yang rasa percaya dirinya tinggi.

Rasa percaya diri diperlukan dimana saja seseorang itu berada, karena itu rasa percaya diri perlu dibangun dan dikembangkan secara positif dan objektif. Siswa sebagai peserta didik yang berfungsi sebagai subjek maupun objek pendidikan dituntut untuk dapat menyesuaikan diri terhadap perubahanperubahan. Penelitian ini bertujuan untuk mengubah seorang siswa yang mempunyai rasa percaya diri rendah menjadi memiliki percaya diri tinggi juga untuk mengetahui seberapa banyak kontribusi layanan konseling dalam menangani masalah pribadi siswa demi keberhasilan.

Hasil penelitian ini diharapkan dapat memberikan sumbangan pemikiran dan jalan keluar langkah-langkah apa yang perlu diambil oleh pihak sekolah, agar keberadaan konseling individu dapat memberikan kontribusi nyata terhadap pengembangan dan peningkatan prestasi belajar siswa.

Lingkup penelitian adalah siswa SMK PGRI 3 Kediri. Untuk menetapkan seorang siswa yang mengalami rasa percaya diri rendah dipergunakan kriteriakriteria tertentu yaitu menunjukkan hasil belajar rendah, hasil yang dicapai tidak sesuai dengan usaha yang dilakukan, sering melamun, menunjukkan perilaku yang berlainan, menunjukkan gejala emosional yang kurang wajar. Untuk mengetahui faktor-faktor penyebab kurangnya rasa percaya diri yang dialami siswa digunakan teknik wawancara, observasi, pencatatan dokumen pribadi untuk faktor internal, sedangkan untuk faktor eksternal adalah lingkungan keluarga dan masyarakat.

Penelitian ini berusaha untuk mengungkap fakta-fakta yang terjadi pada saat penelitian. Fakta-fakta yang dimaksud adalah banyaknya, jenisnya, faktorfaktor penyebab dan upaya penanggulangannya, utamanya menggunakan strategi konseling individual. Fakta-fakta yang terungkap dideskripsikan dengan kata-kata dan tindakan, bukan dengan angka-angka maka penelitian ini menggunakan pendekatan kualitatif.
\end{abstract}

Kata kunci : kurangnya rasa percaya diri.

* Diana Ariswanti Triningtyas adalah Dosen Program Studi Bimbingan dan Konseling Fakultas Ilmu Pendidikan IKIP PGRI Madiun. 


\section{Pendahuluan}

Percaya diri adalah suatu keyakinan pada diri sendiri bahwa dirinya mempunyai kemampuan atau potensi. Faktor dari dalam diri individu (diri sendiri) sangat penting, karena sangat dibutuhkan untuk mencapai tujuan hidup. Kepercayaan pada diri sendiri dapat diamati melalui sikap percaya diri yang meliputi keberanian, hubungan sosial, tanggung jawab dan harga diri.

Pada hakikatnya manusia mempunyai rasa percaya diri, namun rasa percaya diri itu berbeda antara orang yang satu dengan yang lain. Ada yang memiliki rasa percaya diri kurang dan ada yang memiliki lebih, sehingga keduanya menampakkan perbedaan tingkah laku. Jika seseorang mempunyai rasa percaya diri kurang, ia akan menunjukkan perilaku yang berbeda dengan orang pada umumnya seperti tidak bisa berbuat banyak, selalu ragu dalam menjalankan tugas, tidak berani berbicara banyak jika tidak mendapat dukungan dan lain sebagainya kekurangan-kekurangan yang dirasakan. Seseorang yang mempunyai rasa percaya diri lebih, ia merasa yakin dengan kemampuannya sendiri sehingga dapat dilihat tingginya keberanian, hubungan sosial, tanggung jawab serta harga dirinya.

Rasa percaya diri itu bisa dibangun dan dikembangkan secara positif dan objektif sejak anak usia balita. Pengaruh utama dan pertama untuk memasuki kesan-kesan yang menarik bagi anak adalah lingkungan, karena lingkungan merupakan faktor yang pertama anak mengalami perubahan. Anak akan meniru tingkah laku maupun ucapan yang ia lihat, misalnya ketika anak bermain atau bersama teman-temannya, nampak sikapnya yang polos, mau menang sendiri, merebut dan menggunakan mainan yang ia lihat dengan tanpa merasa takut dan malu. Mengingat betapa pentingnya rasa percaya diri ini, maka setiap tempat dan suasana perlu dibangun secara optimal dan positif. Bagi orang tua dan guru diharapkan wajib membantu perkembangan rasa percaya diri pada anak dan samasama saling menyadari bahwa dengan dimilikinya rasa percaya diri yang positif pada diri anak akan membawa keuntungan di berbagai pihak.

Bimo Walgito (1983) memberikan batasan bahwa Self Confidence yaitu kepercayaan pada diri sendiri bahwa dirinya juga mempunyai kemampuan seperti 
teman-temannya untuk mencapai prestasi yang baik. Sejalan dengan pengertian tersebut dalam nada yang berlainan tanpa mengurangi arti, Jalaluddin Rakhmat (1992) menyatakan bahwa keinginan menutup diri, selain karena konsep diri yang negatif timbul dari kurangnya kepercayaan kepada kemampuan sendiri. Seorang yang kurang percaya diri akan cenderung sedapat mungkin menghindari situasi komunikasi.

Ada berbagai penyebab perasaan rendah diri seseorang berkembang lebih kuat dan ada pula yang kurang kuat berkembang. Ketidak-mampuan fisik dapat menyebabkan rasa rendah diri yang jelas, sedangkan kebutuhan manusia yang paling penting adalah kebutuhan akan kepercayaan pada diri sendiri dan rasa superioritas.

Singgih D. Gunarsa (1991) berpendapat bahwa sikap anak yang pasif, rendah diri, mempunyai kecenderungan agresif dan lain sebagainya merupakan faktor yang menghambat anak dalam menampilkan prestasi yang diharapkan. Anak-anak ini biasanya dikarakteristikkan sebagai anak yang mempunyai konsep serta harga diri yang kurang baik dan juga tampak kurang ada rasa aman di dalam dirinya untuk dapat berprestasi dengan baik.

Anak yang penuh percaya diri cenderung lebih tenang dibandingkan dengan mereka yang kurang yakin akan kemampuan dirinya. Mereka tampak tidak gugup menghadapi persoalan atau perubahan lingkungan, sebab mereka merasa cukup dapat menguasai persoalan atau lingkungan tersebut. Disamping itu, anak akan memiliki kemampuan yang lebih besar untuk menempuh resiko dan mencoba hal-hal baru. Sifat-sifat khusus ini akan dijumpai dalam setiap aspekaspek kehidupannya, baik dalam kehidupan sosial, lingkungan pendidikan maupun lingkungan pekerjaan. Orang yang senang akan hal-hal baru banyak memperoleh pelajaran, baik dalam keberhasilannya maupun kegagalannya. Orang semacam ini tidak menganggap kegagalan sebagai sesuatu yang menyedihkan, memalukan dan mematahkan semangat melainkan menjadi tahap untuk memulai langkah berikutnya ke arah keberhasilan. Mereka tidak memandang kesalahan sebagai pertanda ketidak-mampuan atau kebodohan. Kesalahan baginya adalah sesuatu yang wajar terjadi dan oleh karenanya harus dikaji agar dapat dihindari 
atau dikurangi, karena kesemuanya untuk terus berjuang dan pantang menyerang inilah biasanya anak cepat berkembang menjadi seorang ahli dibidangnya. Posisi ini tentu akan semakin mempertebal rasa percaya dirinya. Membina anak hingga memiliki rasa percaya diri berarti menghantar anak tersebut kepada suatu lingkaran atau spiral panjang yang positif dalam kehidupannya. Percaya diri menyebabkan anak menjadi kreatif, senang ber-eksperimen dan berani menempuh resiko. Kesenangan dan keberanian ini akan menghasilkan berkembangnya kecakapan atau kemampuannya; pertambahan kecakapan atau kemampuan akan menambah rasa percaya dirinya; bertambahnya rasa percaya diri menyebabkan bertambahnya kreativitas, dan seterusnya selama hidup si anak. Sebaliknya, anak yang tidak mempunyai rasa percaya diri akan takut ber-eksperimen, tidak kreatif sehingga dengan demikian kecakapan atau kemampuannya kurang berkembang dan ini akan menyebabkan semakin merosotnya rasa percaya diri pada anak tersebut. Berlangsunglah kemudian lingkaran atau spiral panjang negatif sepanjang hidup si anak bila tak terjadi perubahan atau intervensi.

Yang dimaksud dengan kurangnya rasa percaya diri dalam penelitian ini dapat diartikan keinginan menutup diri, selain karena konsep diri yang negatif timbul dari kurangnya kepercayaan kepada kemampuan sendiri. Seorang yang kurang percaya diri akan cenderung sedapat mungkin menghindari situasi komunikasi. Dalam hal ini yang akan diungkap dalam kasus ini adalah seorang siswa yang mempunyai sikap yang berbeda dengan yang lain di kelasnya, yakni sering diam, sering menghela napas panjang, nampak mau menang sendiri, prestasi menurun dan terlihat ketakutan.

Dari uraian latar belakang masalah diatas, maka pertanyaan yang muncul dalam penelitian ini adalah: a) bagaimana rasa percaya diri siswa tersebut; b) faktor apa saja yang mempengaruhi rasa percaya diri siswa tersebut; c) bagaimana memperbaiki atau merubah rasa percaya diri negatif menjadi rasa percaya diri positif.

Sesuai dengan permasalahan yang disajikan, maka penelitian ini memiliki tujuan sebagai berikut: a) menggambarkan rasa percaya diri seorang siswa; b) mengidentifikasi faktor-faktor yang mempengaruhi rasa percaya diri seorang 
siswa; c) mengupayakan jalan keluar untuk memperbaiki atau merubah rasa percaya diri yang kurang menjadi percaya diri.

\section{Metode Penelitian}

Dalam penelitian ini hanya ada satu variabel, yaitu tentang kurangnya rasa percaya diri. Metode penelitian yang digunakan yaitu deskriptif.

Menurut Musyafiqul (1992) dalam bukunya yang berjudul Penelitian Pendidikan, Suatu Pengantar Metodologi Penelitian dan Teknik Penulisan Skripsi, yang dimaksud dengan deskriptif dalam penelitian ini yaitu data yang dikumpulkan berupa kata-kata, gambar, dan kemungkinan data itu menjadi kunci terhadap sesuatu yang sudah diteliti. Dengan demikian, laporan penelitian akan berisi kutipan-kutipan data untuk memberi gambaran penyajian laporan tersebut. Sesuai data yang dikumpulkan, maka peneliti menggunakan pendekatan kualitatif. Dengan alasan dalam kegiatan penelitian ini data dikumpulkan dan digolongkan dalam bentuk dan klasifikasi oleh peneliti.

Tahap penelitian meliputi: a) tahap orientasi, yang diamati adalah tingkah laku siswa juga objek penelitian, disamping itu juga dilakukan pengumpulan data dari berbagai pihak yang terkait seperti dari pihak sekolah sendiri, guru, temanteman, staff sekolah, pihak keluarga, tetangga rumahnya, orang yang mengerti kondisi keluarga anak, hasil laporan perkembangan anak dan dari buku penghubung; b) tahap pendekatan dan penanganan anak, pada tahap ini diciptakan suasana yang dekat dengan anak supaya dapat diketahui kondisi yang sebenarnya terjadi terhadap anak. Sejak ditetapkan bahwa anak tersebut menjadi subjek penelitian, maka anak selalu diamati secara terus menerus baik di dalam maupun di luar sekolah, jika melakukan hal-hal yang terlihat merugikan dirinya. Misalnya, melamun berkepanjangan, maka anak didekati, dibimbing dan diarahkan. Selalu diusahakan untuk sering berkomunikasi dengan anak, dan mencari informasi untuk mendapatkan data-data yang sangat diperlukan pembimbing untuk mengetahui bagaimana cara yang tepat untuk mengatasi anak tersebut; c) tahap ketiga adalah tahap pengambilan kesimpulan, pada tahap ini akan disimpulkan dari semua data yang telah diperoleh. 
Penelitian mengenai studi kasus tentang kurangnya rasa percaya diri seorang siswa, dilakukan di SMK PGRI 3 Kediri, Kota Kediri. Subjek penelitian ini adalah seorang siswa yang duduk di kelas X SMK PGRI 3 Kediri, dengan ciriciri sebagai berikut: a) kurang bisa untuk bersosialisasi dan tidak yakin pada diri sendiri, sehingga mengabaikan kehidupan sosialnya; b) seringkali tampak murung dan depresi; c) suka berpikir negatif dan gagal untuk mengenali potensi yang dimilikinya; d) takut dikritik dan merespon pujian dengan negatif; e) takut untuk mengambil tanggung jawab; f) takut untuk membentuk opininya sendiri; g) hidup dalam keadaan pesimis.

Instrumen dalam penelitian ini adalah menggunakan pedoman observasi, wawancara dan alat pencatat dokumentasi. Pedoman observasi dilakukan untuk mengetahui rasa percaya diri subjek, khususnya pengungkapan rasa percaya diri yang dapat diketahui orang lain mengenai tingkah laku anak di dalam kelas baik terhadap teman, terhadap guru maupun juga diluar kelas, baik terhadap teman yang tidak satu kelas dan terhadap guru yang tidak mengajar di kelasnya. Wawancara dilaksanakan dari anak dan dari sumber data. Banyak data tentang murid yang sudah dicatat dalam beberapa alat pencatat dokumen seperti dalam buku induk, raport, buku pribadi siswa, dan lain sebagainya.

Setelah data terkumpul, maka data tersebut diolah atau dianalisis terlebih dahulu kemudian ditarik kesimpulan. Alasan penelitian ini menggunakan metode diatas karena data tersebut bersifat kualitatif, subjek yang diteliti hanya satu orang dan data yang diperoleh akan diuraikan secara deskriptif.

\section{Hasil Penelitian}

Pengumpulan data yang dilakukan menggunakan beberapa alat serta beberapa sumber dengan peneliti sebagai instrumen utama. Data yang diperoleh tidak disajikan secara keseluruhan dengan pertimbangan faktor urgensi dan relevansi. Untuk menentukan data yang akan disajikan, dilakukan reduksi data serta bagaimana menyajikan dilakukan klasifikasi.

Untuk menjaga kerahasiaan subjek penelitian digunakan nama samaran "Jasmine". Dalam tahap orientasi ini sering ditemukan keganjilan-keganjilan yang 
dilakukan Jasmine. Walaupun sikap dan tindakannya tidak merugikan orang lain, kadang-kadang menghambat proses pembelajaran karena guru sering menghampiri dan waktunya tersita. Guru tertarik ingin memperhatikan secara khusus bila melihat dia sedang mengalami gangguan. Sikap dan tindakannya mengundang rasa belas kasihan, wajahnya pucat, badannya kurus, dan pandangannya kosong.

Tahapa pendekatan dan penanganan anak. Jasmine sering melakukan tindakan-tindakan yang tidak seperti siswa pada umumnya, seperti: sering diam, sering menghela napas panjang, prestasi menurun dan terlihat ketakutan. Dalam penggalian data ditemukan beberapa faktor-faktor yang menyebabkan Jasmine memiliki sikap dan tindakan yang tidak seperti siswa lainnya. Perilaku Jasmine yang tidak mandiri dibentuk dari pola asuh dan pendidikan keluarganya yang selalu melayani dan menyediakan kebutuhan Jasmine sehingga dia tidak memiliki keberanian atau melaksanakan sesuatu.

Perlakuan keluarganya mempengaruhi perkembangan Jasmine, mereka tidak menyadari bahwa tindakannya tidak menjadikan lebih baik malah sebaliknya menjadikan dia kehilangan rasa percaya diri. Untuk keberhasilan seseorang baik itu dalam hal berprestasi, bersosialisasi atau pergaulan senantiasa memerlukan rasa percaya diri.

Sejak kecil Jasmine mudah tersinggung, jika melakukan kesalahan dan mendapat teguran dari orang tua maupun kakaknya dia langsung lari mengurung diri di kamarnya. Kemudian untuk pekerjaan lain dia tidak berani mencoba kalau tidak disuruh. Jasmine sering curiga terhadap teman-temannya yang tertawa dan bicara didekatnya, mungkin mereka membicarakan dan menjelek-jelekkan diri nya. Akibatnya, dia malas bergabung dengan teman-temannya yang sedang mengobrol dan bersendau-gurau. Jasmine mudah putus asa, kegagalan yang dialaminya merupakan musibah yang sangat besar. Kegagalan mencari jati dirinya, kegagalan mencapai peringkat satu merupakan hal yang memalukan. Kegagalannya selalu membayangi dirinya, sehingga dia malas melakukan suatu hal atau malas berusaha agar ia tidak gagal lagi. Dia malas mendengarkan keterangan guru, menurutnya yang menyebabkan tidak dapat mencapai peringkat 
satu adalah guru-gurunya. Pada pelajaran olah raga dia jarang ikut, karena kalau terlalu lelah mudah sakit. Untuk pelajaran yang lain dia mengikuti dengan baik, meskipun dengan meletakkan kepala di bangku atau dengan melamun atau sambil menulis artinya dia tidak pernah bolos sekolah. Jasmine tidak pernah merasa puas dengan apa yang pernah diraihnya. Pada umumnya anak-anak senang kalau mendapat nilai baik atau menang dalam lomba. Jasmine tidak begitu jika tidak mendapatkan nilai baik atau tidak memperoleh juara satu, dia merasa kecewa karena usahanya tidak berhasil.

Penyebab kurang percaya diri pada Jasmine: 1) sikap orang tua. Pola asuh keluarga yang otoriter menyebabkan anak merasa tertekan. Orang tua Jasmine menuntut dia berhasil dalam segala hal, sehingga apabila Jasmine mengalami kegagalan hal ini membuatnya merasa bersalah, putus asa dan krisis percaya diri. Jasmine menganggap di dalam keluarga tidak ada kebebasan bertindak dan berpikir, tekanan mempengaruhi perkembangannya. Selain itu, ketidakharmonisan dalam keluarga Jasmine, membuat dia tidak bisa berbuat apa-apa, sehingga dimanapun berada merasa rendah diri; 2) hubungan sosial dengan lingkungan. Dalam lingkup keluarga, Jasmine selalu diperlakukan seperti anak kecil. Hal ini yang membuat dia tertekan dan tidak dapat mengeluarkan pendapatnya, namun disisi lain dia selalu dimanjakan dan dilayani selama dia mengikuti kehendak ibunya, karena orang tuanya mempunyai harapan yang berlebihan. Di sekolah, Jasmine sulit bersosialisasi terhadap guru, teman-temannya karena dia menganggap tidak ada pihak yang mengerti akan dirinya.

Jasmine memiliki fisik yang normal, tetapi kondisi kesehatannya terganggu. Mudah sakit jika berpikir dan bekerja keras. Hal ini yang menyebabkan Jasmine merasa rendah diri (tidak percaya diri). Jasmine termasuk anak yang pandai, tetapi kemampuan yang dimilikinya tidak mampu mengantar dia meraih keberhasilannya. Akibatnya, kepercayaan atas dirinya berkurang.

Jasmine mempunyai emosi yang kuat, dia termasuk anak yang mudah tersinggung, mudah marah, mudah cemburu, dan mempunyai keinginan yang kuat. Karena emosi yang sering tidak terkendali tersebut mengakibatkan dia sering sakit. Dia sering kecewa terhadap diri sendiri maupun dengan orang lain 
karena pada kenyataannya dia tidak bisa membuktikan bahwa dirinya mampu melakukan sesuatu. Hal ini menyebabkan dia mempunyai rasa percaya diri rendah.

Penanganan terhadap Jasmine dilakukan oleh pihak keluarga dan pihak sekolah. Dilibatkannya keluarga dalam penanganan ini, karena Jasmine lebih banyak di rumah daripada di sekolah. Selain itu pihak keluargalah yang sangat berperan dalam membentuk rasa percaya diri anak. Dengan melibatkan keluarga, diharapkan penanganan terhadap Jasmine mencapai hasil yang maksimal. Upaya penanganan juga melibatkan teman-temannya dan sebagian guru-guru mata pelajaran dan wali kelas maupun guru bimbingan konseling.

Berdasarkan pada data dari penelitian studi kasus tentang kurangnya rasa percaya diri anak, faktor penyebab, dan upaya memperbaikinya, dapat diketahui dan disimpulkan bahwa ketidak-harmonisan keluarga membawa dampak negatif terhadap tingkat perkembangan rasa percaya diri anak, karena anak sebagai korban pelampiasan orang tua ketika terjadi perselisihan di rumah. Perilaku yang muncul pada diri anak yakni menyebabkan anak menjadi takut, tidak berani bicara dan melakukan kegiatan. Hal ini menyebabkan anak tidak mempunyai kemampuan untuk mempercayai dirinya sendiri karena merasa mempunyai kekurangan dibandingkan dengan teman-teman lainnya.

Hasil penelitian dilapangan diperoleh bahwa, tingkat kecerdasan anak mampu mengikuti pelajaran yang diberikan oleh guru bidang studinya. Bimbingan dan perhatian yang diberikan guru pembimbingnya membuat anak semakin mengerti tentang kehidupan dan perbedaan-perbedaan yang harus diterima setiap orang. Namun dalam hal kecerdasan emosi anak masih perlu diperhatikan terus menerus karena kalau pikirannya terganggu masih cemberut. Anak lebih mudah terganggu emosinya bila ada hal yang tidak sesuai dengan apa yang ia inginkan. Anak lebih suka bersifat manja kepada teman-teman dan gurunya, karena ingin mendapat perhatian baru dari orang di luar lingkungan rumahnya.

Dalam rangka penanganan Jasmine dalam upaya merubah rasa percaya diri negatif menjadi rasa percaya diri yang positif tidak lepas dari peranan guru bimbingan dan konseling. Dalam hal ini guru bimbingan dan konseling 
menggunakan konseling eklektik dengan tahapan sebagai berikut: a) tahap eksplorasi masalah, guru bimbingan konseling menciptakan hubungan yang baik dengan Jasmine, membangun kepercayaan, mendengarkan apa yang menjadi perhatian, menggali pengalaman Jasmine pada perilaku yang lebih dalam dan merespon perasaan serta arti dari apa yang dibicarakan Jasmine. b) tahap perumusan masalah, guru bimbingan konseling bersama Jasmine merumuskan masalah, kemudian sepakat dengan rumusan masalah berikut: Jasmine memiliki sikap dan tindakan yang tidak seperti siswa pada umumnya karena dia memiliki rasa percaya diri yang kurang. Oleh karena itu rasa percaya diri negatif harus dirubah menjadi rasa percaya diri yang positif agar Jasmine bersikap dan bertindak seperti siswa pada umumnya. c) tahap identifikasi alternatif, guru bimbingan konseling menawarkan beberapa strategi konseling yang tepat dan realistis serta sangat mungkin dilakukan sedangkan Jasmine bisa memilih beberapa strategi yang ditawarkan tersebut, antara lain: strategi modeling sosial, strategi bermain peran, strategi pengubahan kognitif dan strategi restrukturasi kognitif. d) tahap perencanaan. Beberapa alternatif strategi konseling yang ditawarkan guru bimbingan konseling yang telah dipilih Jasmine adalah: strategi bermain peran, strategi pengubahan kognitif dan strategi restrukturasi kognitif. e) tahap tindakan atau komitmen, guru bimbingan konseling mendorong Jasmine untuk berkemauan melaksanakan rencana-rencana diatas. Usaha Jasmine untuk melaksanakan rencana ini sangat penting bagi keberhasilan konseling, karena tanpa ada tindakan nyata proses konseling tidak berarti. f) tahap penilaian dan umpan balik. Guru bimbingan konseling serta Jasmine mengadakan penilaian tentang hasil yang dicapai. Pada kenyataannya proses konseling telah banyak menampakkan hasil, yaitu dengan adanya banyak perubahan tingkah laku Jasmine sudah tidak sering malu dan sering takut. Percaya dirinya sudah baik terlihat dari komunikasi dengan guru-guru dan teman-temannya sudah sempurna. Terbukti, raut mukanya tampak lebih cerah dibanding sebelumnya. Oleh karena itu proses konseling sangat perlu dipertahankan.

Dengan bertambahnya tingkat usia dan pengetahuan anak, maka anak dapat mengerti dan memahami kebiasaan buruk yang dilakukan. Dengan 
demikian ia dapat merubah sikapnya yang kurang baik menjadi lebih baik. Kegiatan yang dilakukan anak sudah mulai menuju pada kegiatan yang positif. Anak mulai dapat memahami arti dari kasih sayang yang selama ini ia dambakan. Anak lebih suka bersikap tenggang rasa dengan guru dan teman-temannya.

Dengan memperhatikan hasil penelitian diatas, beberapa saran yang perlu penulis sampaikan: Pertama, kepada pendidik dimana saja untuk meningkatkan pengertian dan pemahaman terhadap anak yang bermasalah. Dan memberikan cinta kasih serta kegembiraan kepada anak didik dalam upaya penanganan anak bermasalah. Dengan demikian diharapkan ketercapaian tujuan untuk penanganan anak bermasalah dapat segera diatasi dengan mudah. Kedua, kepada kepala sekolah disarankan untuk membantu kelancaran pelaksanaan dalam penanganan anak bermasalah melalui pembinaan kepada wali kelas dan guru-guru bidang studi supaya memperhatikan anak didiknya terutama mereka yang bermasalah. Perhatian yang diberikan berupa pemahaman, pengertian dan kasih sayang dengan penuh kesabaran. Disarankan juga untuk selalu mengikut-sertakan dalam kegiatan seminar, pelatihan, atau bimbingan teknik yang lain yang terkait dengan tugas pendidik dalam menangani anak terutama anak yang bermasalah. Ketiga, kepada orang tua diharapkan untuk bersikap bijaksana terhadap anak dan meningkatkan perhatian sehingga merasa mendapat kasih sayang yang tulus. Komunikasi orang tua terhadap guru sangat diperlukan untuk mengetahui perkembangan anaknya sehingga memudahkan penanganan bila anak sedang bermasalah.

\section{Daftar Pustaka}

Ahmadi, Abu \& Supriyono W. 2004. Psikologi Belajar. Jakarta : Rineka Cipta.

Baribara de Angelis. 2003. Confidence (Percaya Diri). Jakarta : Gramedia Pustaka Utama.

Gunarsa, Singgih D. 1991. Psikologi untuk Keluarga. Jakarta : PT. BPK Gunung Mulia.

Hamzah, Rohmulyati \& Waitley, Denis. 1994. 10 Benih-Benih Kebebasan. Jakarta : Bina Rupa Aksara.

Hardjono, AM. Mangun. 1992. Mengatasi Hambatan-hambatan Kepribadian. Yogyakarta : Kanisius.

Hurlock, B. Elizabeth. 1991. Perkembangan Anak. Jilid 1. Terjemahan. Jakarta : Erlangga.

Hartono, Bambang. 1997. Melatih Anak Percaya Diri. Jakarta : Gunung Mulia. 
Jan Dargantz. 1999. Cara Membangun Harga Diri \& Percaya Diri Anak. Jakarta : Pustaka Tangga.

Loekmono J.T., Lobby. 1992. Harga Diri. Semarang : Satyawacana.

Mappiare, Andi. 1982. Psikologi Remaja. Surabaya: Usaha Nasional.

Meadow, Mary Jo. 1991. Memahami Orang Lain. Semarang : Satyawacana.

Muh. Farozin \& Kartika Nur F. 2004. Pemahaman Tingkah Laku. Jakarta : Rineka Cipta.

Musyafiqul, Achmad. 1992. Penelitian Pendidikan. Suatu Pengantar Metodologi Penelitian dan Teknik Penulisan Skripsi. Kediri : UNP.

Moh. Nur \& Masitah. 1999. Psikologi Pendidikan Pondasi untuk Pengajaran. Universitas Negeri Surabaya.

Poduska, Bernard. 1991. Empat Teori Kepribadian. Jakarta : Tunas Jaya.

Pudjosuwarno, Sayeksti. 1994. Bimbingan Konseling dan Keluarga. Yogyakarta : Menara Mas Offset.

Purwanto, Ngalim. 1993. Psikologi Pendidikan. Bandung : Remaja Rosdakarya.

Sadli, Saparinah. 1977. Persepsi Sosial Mengenai Perilaku Menyimpang. Jakarta : Bulan Bintang.

Siahaan, Henry N. 1991. Peranan Ibu Bapak Mendidik Anak. Bandung: Angkasa.

Subrata, Hadi. 1990. Mengembangkan Citra Diri yang Positif. Bogor : Nurani Yuana.

Sunaryo, dkk. 2001. Pendidikan Budi Pekerti. Jakarta : Dikdasmen.

Sujanto, Agus. 1984. Psikologi Kepribadian. Jakarta : Aksara Baru. 